\title{
АНАЛІЗ ОСНОВНИХ ПРОБЛЕМ ЕНЕРГЕТИЧНОЇ ГАЛУЗІ УКРАЇНИ
}

\author{
Маковоз О.В., к.е.н., доцент (УкрДУЗТ) \\ Глазкова А.С., к.е.н., доцент (ХНУ імені В.Н. Каразіна)
}

У статті проаналізовано сучасний стан енергетичної галузі, наведені основні показники діяльності та виявлені основні економічні проблеми енергетичної галузі України. Забезпечення ефективності функиіонування енергетичної галузі країни багато в чому залежить від дієвого управління, яке трунтується на аналізі основних проблем формування та розвитку ціієі галузі та систематизації факторів підвищення результативності діяльності галузі. На основі системного підходу здійснено аналіз проблем та зроблені відповідні висновки.

Ключові слова: енергетична галузь, економіка, системний аналіз, ефективність, розвиток.

\section{АНАЛИЗ ОСНОВНЫХ ПРОБЛЕМ ЭНЕРГЕТИЧЕСКОЙ ОТРАСЛИ УКРАИНЫ}

\author{
Маковоз Е.В., к.э.н., доцент (УкрГУЖТ) \\ Глазкова А.С., к.э.н., доцент (ХНУ имени В.Н. Каразина)
}

\begin{abstract}
В статье проанализировано современное состояние энергетической отрасли, приведены основные показатели деятельности и выявлены основные экономические проблемь энергетической отрасли Украины. Обеспечение эффективности функционирования энергетической отрасли страньи во многом зависит от эффективного управления, основанное на анализе основных проблем формирования и развития этой отрасли и систематизации факторов повышения результативности деятельности отрасли. На основе системного подхода проведен анализ проблем и сделаны соответствуюшие выводы.
\end{abstract}

Ключевые слова: энергетическая отрасль, экономика, системный анализ, эффективность, развитие.

\section{ANALYSIS THE MAIN PROBLEMS OF THE UKRAINE'S ENERGETIC INDUSTRY}

\author{
Makovoz O.V., Candidate of Economic Sciences, Associate Professor (USURT) \\ Glazkova A.S., Candidate of Economic Sciences, Associate Professor (KhNU named \\ after V.N. Karazin)
}

The article analyzes the current state of the energy industry, presents the main indicators of activity and reveals the main economic problems of the energy industry of Ukraine. The efficiency of the functioning of the country's energy industry depends largely on the analysis of the main problems of the formation and development of this industry and the systematization of aspects of its effective operation. The regional energy industry is a set of

(C) Маковоз О.В.,

Глазкова А.С.

Вісник економіки транспорту і промисловості № 63, 2018 
economic entities connected with technological, economic, financial flows and interconnected processes of production, transmission, sales and consumption of resources in the region and related financial and economic relations. On the basis of the systematic approach, a systematic analysis of problems was carried out and relevant conclusions were drawn. A characteristic feature of Ukraine's energy is that it was formed as an integral part of the fuel and energy complex of the former Union, which does not fully correspond to the current conditions of functioning of energy in an independent state. During the period of market reform of the Ukrainian economy in the energy sector there was a situation characterized by the following problems: a high proportion of physically and morally worn out or completely obsolete fixed assets, which may lead not only to the limitation of electricity supply in certain regions, but also to the violation of the integrity of the Ukrainian energy system; low energy efficiency, resulting from high energy intensity; the imperfection of the state's economic policy in the energy sector, which does not allow to provide real self-financing of the current activity of the industry; not the formation of a competitive energy market and the corresponding market infrastructure of tariffs; lack of energy conservation motivation; ineffective tax policies, etc.

Key words: energy branch, economy, system analysis, efficiency, development.

Постановка проблеми. Під впливом процесів реформування економіки в Україні поступово складається нова економічна система, яка включає в себе різноманітні аспекти, пов'язані з утворенням нових економічних відносин між суб'єктами господарювання. Неодмінною складовою переходу України до європейських ринкових відносин $\epsilon$ створення нового систематизованого підходу до економічних аспектів діяльності підприємств всіх галузей економіки як єдиного комплексу. Однією 3 основних галузей економіки $є$ енергетична галузь. Ефективність функціонування енергетичної галузі країни багато в чому залежить від аналізу основних проблем формування та розвитку цієї галузі та систематизації аспектів ii ефективної діяльності.

Енергетична галузь являє собою сукупність господарюючих суб'єктів, пов'язаних між собою технологічними, економічними, фінансовими потоками та взаємопов'язаними процесами виробництва, передачі, збуту і споживання ресурсів в регіоні і відповідними фінансово - економічними відносинами. Тому, основною невирішеною проблемою, на наш погляд, являється пошук шляхів забезпечення функціонування галузі на основі аналізу та систематизації основних проблем діяльності галузі.

\begin{tabular}{lccr}
\multicolumn{2}{c}{ Аналіз } & останніх & досліджень \\
публікацій. & Вагомий & внесок & у \\
формування & сучасних & теорій & та
\end{tabular}
практичних аспектів функціонування i розвитку енергетичної галузі України зробили такі вчені, як Пономаренко O.I. [1], Беляєв Л.С. [2], Бондаренко В.М. [3], Бандман М.К.[4], Бізяркіна О.М. [5], Богославська О.Ю. [6] та ін,. В працях вчених досліджені основні умови функціонування енергетичного комплексу та встановлені основні інституційні середовища його функціонування i розвитку, проаналізовані позитивні та негативні фактори впливу, які разом впливають на ефективність функціонування підприємств енергетичної галузі. Також існуючі проведені дослідження у вітчизняній i зарубіжній науці показують певні закономірності формування та розвитку енергетичної галузі [11].

Виділення невирішених частин загальної проблеми. У період ринкового реформування економіки України в енергетичній галузі склалася ситуація, що характеризується наступними проблемами: високою часткою фізично та 
морально зношених або зовсім застарілих основних фондів, що може призвести не тільки до обмеження електропостачання в окремих регіонах, але i до порушення цілісності енергетичної системи України; низькою ефективністю використання енергоресурсів, що $\epsilon$ наслідком високої енергоємності; недосконалістю економічної політики держави в енергетичній сфері, що не дозволяє забезпечувати реальне самофінансування поточної діяльності галузі; не сформованістю конкурентного енергетичного ринку та відповідної ринкової інфраструктури тарифів; відсутністю мотивації енергозбереження; неефективною податковою політикою, тощо.

Характерною рисою енергетики України $\epsilon$ те, що вона була сформована як складова частина паливно-енергетичного комплексу СРСР, що не повною мірою відповідає сучасним умовам функціонування енергетики в незалежній державі.

Мета статті. Для правильного розуміння процесів формування та розвитку сучасної енергетичної галузі необхідно здійснити аналіз економічних проблем, 3 якими стикаються суб'єкти енергетичної галузі у сучасному середовищі господарювання, систематизувати їх на основі аналізу статистичних даних та надати пропозиції щодо виходу енергетичної галузі 3 економічної кризи.

Виклад основного матеріалу.

Енергетична система (ЕС) України, включає в себе вісім регіональних електроенергетичних систем Дніпровську, Донбаську, Західну, Кримську, Південну, Південно-Західну, Північну i Центральну. До складу ЕС України входять: 4 AЕC, 14 TEC, 7 ГЕС, 3 ГАЕС, 97 ТЕЦ, малі ГЕС, ВЕС та інші загальною встановленою потужністю 54504,4 МВт, близько 23 тис. км магістральних та міждержавних електричних мереж напругою 220-750 кВ та 996 тис. км розподільчих мереж напругою $0,4-150$ кВ.

Рівень розвитку економіки будьякої країни знаходиться в прямій залежності від використання електроенергії, яку можна назвати найуніверсальнішою енергією. Щорічно підвищується рівень іii виробництва та споживання. У світі в цілому спостерігаються позитивні тенденції, тобто щороку збільшуються як потужності електростанцій, так i виробництво електроенергії взагалі та на душу населення. В той же час, така тенденція притаманна не всім країнам. Зокрема, в країнах Східної Свропи, а особливо, колишнього СРСР, при збереженні встановлених потужностей електростанцій, виробництво електроенергії значно скорочувалося. В результаті багатьох досліджень був виявлений зв'язок між виробництвом електроенергії та доходом на душу населення [5; 6]. Встановлено, що чим вищий показник виробництва електроенергії на душу населення, тим більший доход на душу населення [7]. Тому, природним є бажання країн, які розвиваються, підвищити рівень життя громадян шляхом збільшення виробництва електроенергії на душу населення на рік. Структура економіки України характеризується великою питомою вагою енерго- та паливомістких виробництв за відсутності необхідних обсягів паливно-енергетичних ресурсів в результаті використання застарілих технологій і обладнання в промисловості. Усім вищесказаним обумовлюється те, що за рівнем питомого споживання енергоресурсів у промисловості, Україна посідає одне 3 перших місць у світі. Як наслідок, енергоємність ВВП $\epsilon$ надзвичайно високою. В Україні спостерігається нетипова ситуація: енергоємність ВВП зростає з паралельним зменшенням споживання енергії на душу населення. Таким чином, ВВП зростає набагато менше, аніж енергоспоживання - 
в результаті чого зростає його енергоємність.

В проекті концепції «Національної енергетичної стратегії на період до 2030 року» вченими передбачається щорічне зменшення як енергоємності, так і паливо ємності ВВП України [8,9]. До 2030 р. електроємність ВВП за песимістичним сценарієм скоротиться майже в половину - на 48,39\%, за базового сценарію - на
$57,40 \%$, а за оптимістичного - на 66,67\%. Щодо паливоємності ВВП, то в 2030 p. вона дорівнюватиме 42,0\%, 34,2\%, 25,9\% рівня 2000 р. за песимістичного, базового та оптимістичного сценаріїв відповідно. Для більш наочного розуміння стану енергетичної галузі на рисунку 1 наведено динаміку електроємності ВВП України на період 2000-2025 рр.

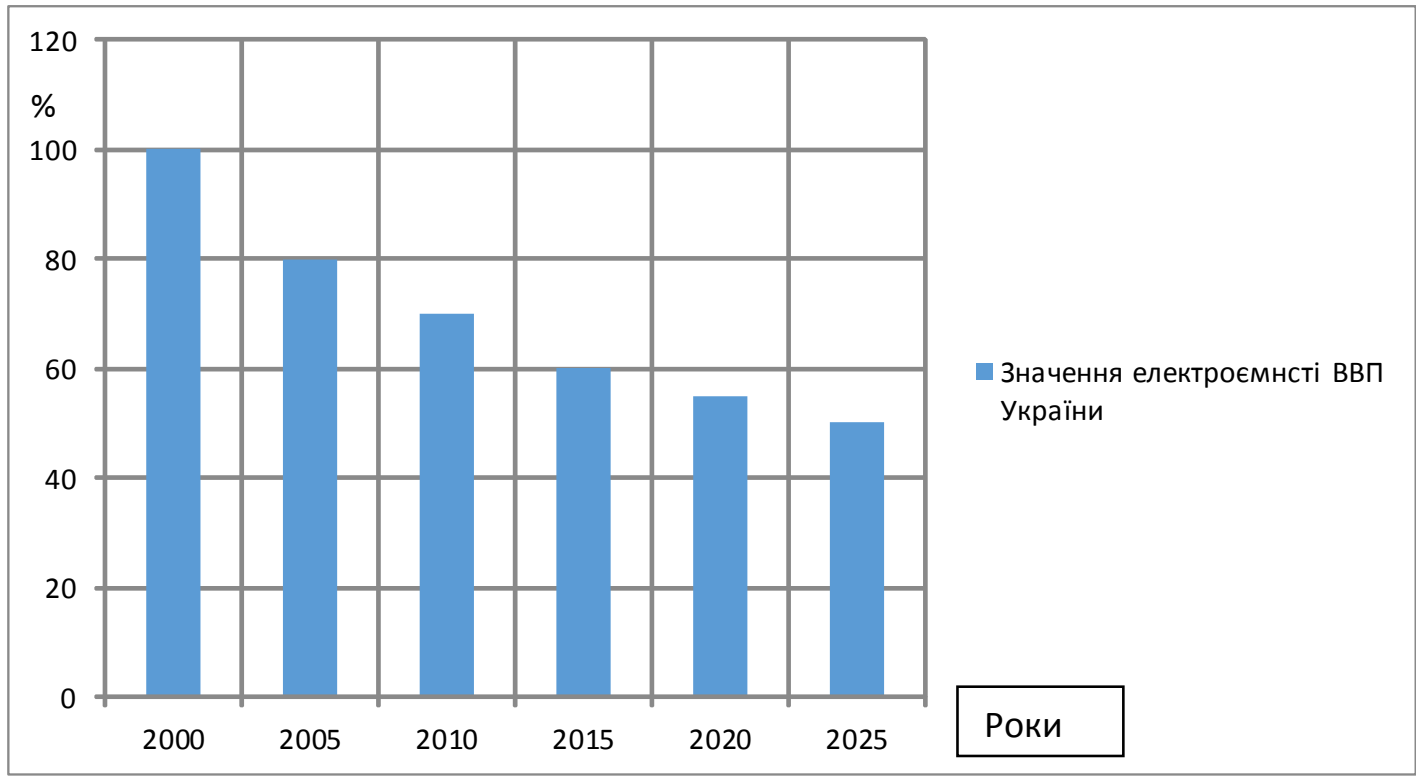

Рис. 1. Динаміка електроємності ВВП Украӥни за nерiod 2000-2025 pp. [10]

Характерною

рисою електроенергетики України $є$ те, що вона була сформована як складова частина паливно-енергетичного комплексу колишнього Союзу, що не повною мірою відповідає умовам функціонування енергетики в незалежній державі. У період ринкового реформування економіки України в енергетиці склалася ситуація, що характеризується такими проблемами: високою часткою фізично та морально застарілих основних фондів, що може призвести не тільки до обмеження електропостачання в окремих регіонах, але i до порушення цілісності енергетичних об'єктів України; низькою ефективністю використання енергоресурсів, що $є$ наслідком високої енергоємності; економічної політики держави в енергетичній сфері, що не дозволяє забезпечувати реальне самофінансування поточної діяльності енергетичної галузі; недосконалістю конкурентного енергетичного ринку та відповідної ринкової інфраструктури тарифів; відсутністю мотивації економії енергоресурсів; неефективною податковою політикою, тощо. Таким чином, проаналізувавши ситуацію, яка склалася на національному ринку енергетики можна прийти до такого висновку. По-перше, з 1990 р. до 2000 р. в Україні був відмічений значний спад виробництва та споживання продукції підприємств паливно-енергетичного 
комплексу, і тільки з 2001 р. відбувається поступове зростання цих показників. Подруге, негативним моментом $є$ те, що надзвичайно високою є питома вага втрат електроенергії в мережах загального користування [3, 4]. Причиною вагомого зростання технологічних втрат при транспортуванні електроенергії $\epsilon$ : незадовільний стан електричних мереж, а також невідповідність електричних мереж існуючим рівням та режимам енергоспоживання. Цим обумовлюється необхідність розробити та вжити ряд заходів щодо скорочення втрат палива та електроенергії в процесі виробництва, неконтрольованого використання ресурсів, а також розкрадання. Також більше виробляється електроенергії, аніж $\epsilon$ необхідність в ній. В той же час, рівень споживання як нафти, так і природного газу набагато перевищує рівень їх видобутку. В зв'язку 3 цим, по можливості, потрібно досягти максимального рівня забезпеченості паливно-енергетичними ресурсами власного виробництва.

Варто вказати, що стримування економічного росту не обов'язково має бути обумовлене енергетичною залежністю від зовнішніх джерел. Досягнення певного рівня i темпів економічного зростання та відповідно економічної і енергетичної ефективності країни призводить до збільшення енергоспоживання за рахунок імпорту. Фактори розвитку енергоспоживання та інші фактори, такі як геополітичні пріоритети, географічне розташування, можуть так чи інакше впливати на відхилення від загальної тенденції. Для України частка імпорту в загальному первинному споживанні залежить, певним чином, від геополітичної стратегії та можливості диверсифікації імпорту. Так енергетична залежність України від Росії $\epsilon$ надзвичайно високою. Україна імпортує 3 Росії близько 76\% від загального обсягу споживання природного газу, 65\% нафти
$[11,12]$. Таким чином , в результаті проведеного аналізу, можна систематизувати економічні проблеми енергетичної галузі (рис.2)

Висновок. В результаті проведеного дослідження проблем енергетичної галузі в статті визначено внутрішні та зовнішні чинники, які впливають на діяльність підприємств енергетичної галузі. Серед основних економічних проблем слід відзначити: незбалансованість структури генеруючих потужностей, нестача ресурсів для ефективного регулювання потужності та частоти; спрацьованість i технічна застарілість обладнання; недостатня пропускна спроможність низки системоутворюючих ЛЕП для передачі потужності; недостатні обсяги засобів регулювання напруги та компенсації реактивної потужності; недостатній рівень оснащеності засобами телемеханіки, релейного захисту та автоматики, моніторингу та діагностики; недосконалість систем диспетчерського керування.

\section{ПЕРЛІК ВИКОРИСТАНИХ ДЖЕРЕЛ}

1. Пономаренко О.I. Системний аналіз в управлінні / O.I. Пономаренко Проблеми науки. - 2004. - № 4. - с.7.

2. Шарапов О.Д. Системний аналіз. Навч-метод. посібник для самостійного вивчення дисципліни. / О.Д.Шарапов, В.Д.Дербенцев, Д.Є. Семьонов. - К.:КНЕУ, 2003. - 154c.

3. Беляев Л. С. Системный подход при управлении развитием электроэнергетики / Л.С. Беляев, Г.В. Войцеховская, В.А. Савельев и др. Новосибирск: Наука, 1980. — 212c.

4. Бондаренко В. М. Новая методология познания - ключ к формированию новой динамической модели развития общества / В. М. Бондаренко // Устойчивое развитие. Наука и практика. - 2004. - № 4. - С.7 - 12. 


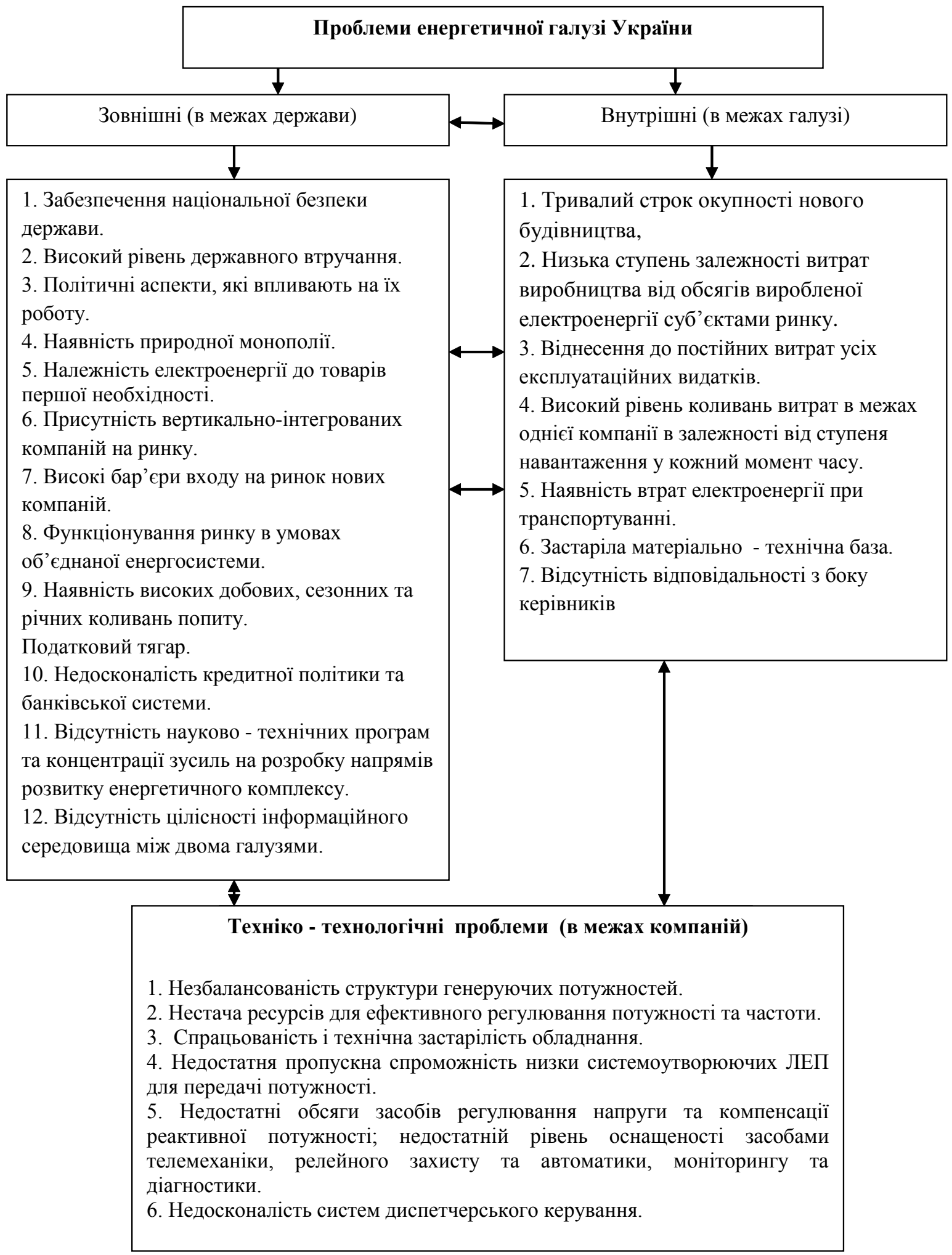

Рис. 2. Проблеми енергетичної галузі України 
5. Бандман М. К. Методы и модели разработки региональных энергетических программ / М. К. Бандман. - Новосибирск: Наука, 2003. 139 c.

6. Бизяркина Е. Н. Экологически устойчивое социально-экономическое развитие: основы теории и методологии: автореферат дис. доктора екон. наук: 08.00.05 / Бизяркина Елена Николаевна. M., 2008. - 48 c.

7. Богославська О.Ю. Моделювання та розробка цінових стратегій теплових електростанцій на оптовому ринку електроенергії України: автореф. дис. канд. екон. наук: 08.00.11/ Богославська Ольга Юріївна; ДУ "Ін-т економіки та прогнозування НАН України". - К., 2010. - 20 с.

8. Барановський В. До концепції переходу України на модель сталого розвитку / В. Барановський // Економіка України. - 2001. — №7. - С. 78-83;
9. Берталанфи Л. Ф. Общая теория систем / Л. Ф. Берталанфи - М.: Путь, 2000. - $400 \mathrm{c}$.

10. Турбіна O. I. Динаміка розвитку електроенергетичної системи регіону / О. I. Турбіна // Прометей. Регіональний зб. наук. праць. Вип. 2(74). - Донецьк: ДЕГІ, 2011. - С. 97-105.

11. Владивосток - Лиссабон: путь к энергобезопасности. По материалам международной брюссельской конференции по вопросу объединения энергосистем // Энергетическая политика Украины. - 2014. - № 2. - С.64 -67.

12. Дикань В.Л., Зубенко В.О., Токмакова I.В., Маковоз О.В., Шраменко О.В. Стратегічне управління: навчальний посібник. - К.: «Центр учбової літератури», 2013. - 272 с.

13. Беляев Л. С.

Электроэнергетические системы и рынок в электроэнергетике // Л.С. Беляєв. Энергия: экономика, техника, экология. 2010. — № 1. - C. $10-17$.

\title{
РОЛЬ ПІДПРИЕМСТВА В ЕКОЛОГІЧНІЙ МОДЕРНІЗАЩІЇ НАЦІОНАЛЬНОЇ ЕКОНОМІЧНОЇ СИСТЕМИ
}

\author{
Маценко М.А., к.е.н., доцент (ХНЕУ ім. С. Кузнеця)
}

В статті проаналізовано роль підприємства в формуванні $i$ подальшому розвитку екологічної модернізації національної економічної системи в інноваційному підході до екологічної безпеки підприємства та держави в міжнародній екологічній безпеці. Визначено, щзо кожне підприємство країни має забезпечити екологічну безпеку свого виробництва, товарів, послуг через проведення грамотної та довготривалої екологічної політики. Запропоновано механізм модернізації національної економічної системи в сфрері економічної безпеки відповідно міжнародним вимогам та для успішної реалізації в Україні концепиії сталого розвитку.

Ключові слова: національна економічна система, екологічна безпека, інноваційне реформування, екологічна політика, екологічна модернізація. 